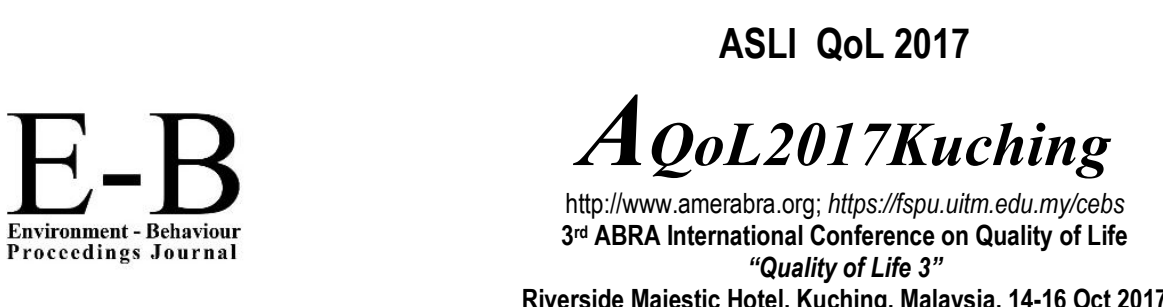

Riverside Majestic Hotel, Kuching, Malaysia, 14-16 Oct 2017

\title{
Assessment of Heritage Property Values Using Multiple Regression Analysis and Rank Transformation Regression
}

\author{
Junainah Mohamad ${ }^{1}$, Suriatini Ismail ${ }^{2}$, Abdul Hamid Mar Iman ${ }^{3}$, Thuraiya Mohd 4 \\ 1,4 Faculty of Architecture, Planning \& Surveying, Universiti Teknologi MARA, Perak Branch, Seri Iskandar Campus, Seri Iskandar, 32610 Perak, Malaysia \\ ${ }^{2} 2$ Faculty of Architecture and Ekistics, Universiti Malaysia Kelantan, Bachok Campus, Bachok, 16300 Kelantan, Malaysia \\ 3Faculty of Earth Sciences, Universiti Malaysia Kelantan, Jeli Campus, Jeli, 17600 Kelantan Malaysia \\ mjunainah@uitm.edu.my \\ Tel: $+6012-7123044$
}

\begin{abstract}
The aim of this paper was to test the applicability of multiple regression analysis and rank transformation regression in assessing the values of private heritage property. The original dataset consists of 893 commercial properties transacted from 2004 to 2014 in Kelantan Malaysia. After filtration process, only 25 units of shophouse heritage property were available and valid to be used. The models have been constructed and their statistical performances have been compared. The results indicate that adopting statistical methods of valuation per se to overcome the issue of unavailability of market evidence could not solve the consequences of the limited data problem.
\end{abstract}

Keywords: real estate valuation; heritage property; multiple regression analysis; rank transformation regression

eISSN: 2398-4287C 2017. The Authors. Published for AMER ABRA by e-International Publishing House, Ltd., UK. This is an open access article under the CC BYNCND license (http://creativecommons.org/licenses/by-nc-nd/4.0/). Peer-review under responsibility of AMER (Association of Malaysian Environment-Behaviour Researchers), ABRA (Association of Behavioural Researchers on Asians) and cE-Bs (Centre for Environment-Behaviour Studies), Faculty of Architecture, Planning \& Surveying, Universiti Teknologi MARA, Malaysia.

https://doi.org/10.21834/e-bpj.v2i6.972

\subsection{Introduction}

Interest in the valuation of heritage property has increased, particularly in determining the appropriate approach to value heritage properties. Our heritage is a legacy from our past. It something that we live now in hope to pass to future generations. Despite the importance as history to future generations, there is no guarantee that heritage will survive and be transferred to the next generations, and for this reason, in recent years, several countries have attempted to protect and preserve the heritage property. Valuation is a part of a decision-making process for the preservation and protection of the heritage property.

Yet, the valuation of heritage property has been met with many challenges over the time. The valuation of heritage property differs from the valuation of other kinds of asset because heritage property is not traded actively in the market. The fundamental aspects of heritage property valuation are different depending on the type of heritage property, purpose of valuation, parties' conducting valuation and types of heritage property.

Heritage property can be classified into two which are for public goods and private goods, and both types apply different valuation approaches. The most popular method used in valuing public goods of heritage property is contingent valuation method (CVM), which is falls under stated preference (SP) category. While, for private heritage property, based on current practice in Malaysia, the practitioner uses the sale comparison approach to value heritage property. However, there is limitation in applying this approach because of limited market evidence and recent date of transaction.

To overcome these issues (limited market evidence), the market value of private heritage property can be determined by using statistical method of analysis i.e multiple regression analysis (MRA). However, problem may arise in data processing if the dataset does not contain enough observations per independent variables to run a statistically acceptable regression model (VanVoorhis and

eISSN: 2398-4287C 2017. The Authors. Published for AMER ABRA by e-International Publishing House, Ltd., UK. This is an open access article under the CC BYNCND license (http://creativecommons.org/licenses/by-nc-nd/4.0/). Peer-review under responsibility of AMER (Association of Malaysian Environment-Behaviour Researchers), ABRA (Association of Behavioural Researchers on Asians) and cE-Bs (Centre for Environment-Behaviour Studies), Faculty of Architecture, Planning \& Surveying, Universiti Teknologi MARA, Malaysia.

https://doi.org/10.21834/e-bpj.v2i6.972 
Morgan 2007). In fact, the market evidence of heritage property is limited because the transaction is not frequently occurred. Sometimes, only around 20 transactions are available for a period of more than 10 years. This is also supported by International Valuation Standards 2011-Annexe A11, which states that in some cases, heritage property may be incapable of reliable valuation because there is no relevant market evidence. Therefore, to overcome thin market issue, Mohamad (2012) has evidenced that rank transformation regression (RTR) is capable to be run in small sample of observations. The study reported, the statistical results of mean squared error (MSE) of RTR are smaller than MRA in small sample observations and thus the aim of this study is to test the applicability of MRA and RTR in assessing the value of private heritage property with limited market evidence.

The remainder of the paper is organized as follows. In Section 2, the literature for heritage property valuation and the methods used in valuing heritage property are presented. In section 3, the study area and research methodology are described. Section 4 presents the empirical results on applicability of MRA and RTR in assessing the value of heritage property and the models are evaluated based on their statistical performance. Section 5 concludes the paper and suggests some potentially fruitful avenues for future research.

\subsection{Literature Review}

\subsection{Valuation of heritage property}

Valuation is a critical stage in the activities that relate to preservation and maintenance of cultural heritage, including built cultural heritage. However, there is little knowledge or lack of studies on how heritage properties are assessed (Yung and 容曉君, 2007). The term valuation has a different spectrum of implications. A world of difference based on philosophy, parties conducting a valuation, purpose for which it is carried out and, thus, the practice of valuation itself. It is important to understand the differences between market valuation and economic valuation of heritage property. Tables 1 differentiate the fundamental aspects of market valuation and economic valuation.

Table 1. Fundamental aspects of market valuation and economic valuation

\begin{tabular}{|c|c|c|c|}
\hline No & Fundamental aspects & Market Valuation & Economic Valuation \\
\hline 1. & Purpose of valuation & $\begin{array}{l}\text { Transactional } \\
\text { (sale and purchase, rates, lease, tenancy, } \\
\text { acquisition, etc) }\end{array}$ & Conservational \\
\hline 2. & The philosophy of valuation & $\begin{array}{l}\text { Resource consumption for the welfare of the } \\
\text { individual person }\end{array}$ & $\begin{array}{l}\text { Resources planning and management welfare } \\
\text { of the society }\end{array}$ \\
\hline 3. & Parties conducting valuation & $\begin{array}{l}\text { Valuers } \\
\text { (Valuers carryout valuation according to standards } \\
\text { as well as methods sanctioned in the standards) }\end{array}$ & $\begin{array}{l}\text { Economists } \\
\text { (Economists do not have what is called } \\
\text { valuation standards but they have methods) }\end{array}$ \\
\hline 4. & Types of heritage property & $\begin{array}{l}\text { Grade II, Grade III } \\
\text { (transacted) } \\
\text { Private heritage property }\end{array}$ & $\begin{array}{l}\text { Grade I } \\
\text { (nontransacted) } \\
\text { Public goods of heritage property }\end{array}$ \\
\hline
\end{tabular}

\subsection{Factors Affecting Heritage Property Value}

In general, the variables affecting property prices are size of property, geographical position, and maintenance condition. Nevertheless, in heritage property valuation, question arises as to which historical characteristics influence the property prices. As Ruijgrok (2006) pointed out, there has been no studies on the factors that influence heritage property prices. Factors influencing the heritage property values can be broadly divided into (4) four groups, namely transaction-related characteristics, structural characteristics, location characteristics, and historical characteristics. The following subsection briefly discusses the factors affecting heritage property values. Figure 2 illustrates the factors affecting heritage property values.

\section{Transaction-related Characteristics}

Sale prices are used as control variable (dependent variable). According to Royal Institution of Chartered Surveyors, sale prices are the most reliable data source in assessing property values because it has been purely exposed in the open market value. Othertransaction related characteristics are land/building status (freehold/leasehold), year of valuation, building position, lot number and building number.

\section{Structural Characteristics}

The structural property characteristics data were obtained from the same sources as the sale price data. Structural characteristics in this study include lot size, main floor area, building improvement, roof material, types of floor, types of ceiling, building material, and maintenance condition (outside/inside). To ensure the quality of structural characteristics, a site inspection was conducted to conform all related structural characteristics, including any new renovation.

\section{Location Characteristics}

The importance of location in determining property value has been widely discussed in the literature (Iman \& Chin, 2005; Boyce, Kinnard Jr, \& Kinnard, 1984; Deddis, 2002; McCluskey, Deddis, \& Lamont, 1998). It is said that the main factors that influence property value are location, location, and location (Boyee \& Kinnard, 1984). A demand rate for a particular property is affected by 
location (McCluskey \& Deddis, 1998). This statement is supported McCluskey and Deddis (1998), who suggested that location is the dominant factor to understand property demand. Locational factors are related to accessibility to work, amenities, transportation, physical attributes, neighbourhood, and environment quality, among others. All these factors are related to location (Iman \& Chin, 2005). Commonly, the assessors obtain the information for the subject property based on the subjects' location. For instance, areas with high crime rates have low property values compared to areas with low crime rate for similar properties. Location within a city is the most important factor in the property market (Kim, 2005). A proxy for locational factor is distance, which is the length of physical separation between a property to the central business district (CBD).

\section{Historical Characteristics}

The listed historical characteristics used in this study are mainly based on Ruijgrok (2006), this is the only work found to have taken into account the historical characteristics in hedonic pricing model development. The historical characteristics include façade status, architectural style, ensemble, and authenticity. After the historical factors are identified, the problem is how to measure it. The study measures historical characteristics as categorical variables that are divided into several classes. For example "architectural styles" is classified into three groups: romantic, functionalistic, and modern, whereas "authenticity" looks at the area of façade, window frames, and colors of original materials. If all three are intact, then the pre-war shophouse falls in class 1 . If one or two of these three are intact, then the pre-war house falls in class 2 , and if all are not intact, then the property falls in class 3 . The variable ensemble was measured by looking at the left, right, and cross the neighbourhood are facing in same architectural style. If all have the same architectural style (maintaining legacy image), the property falls in class 1 ; if one or two have the same architectural style, the property falls in class 2; and if everything is different in the neighbohood, the property falls in class 3.

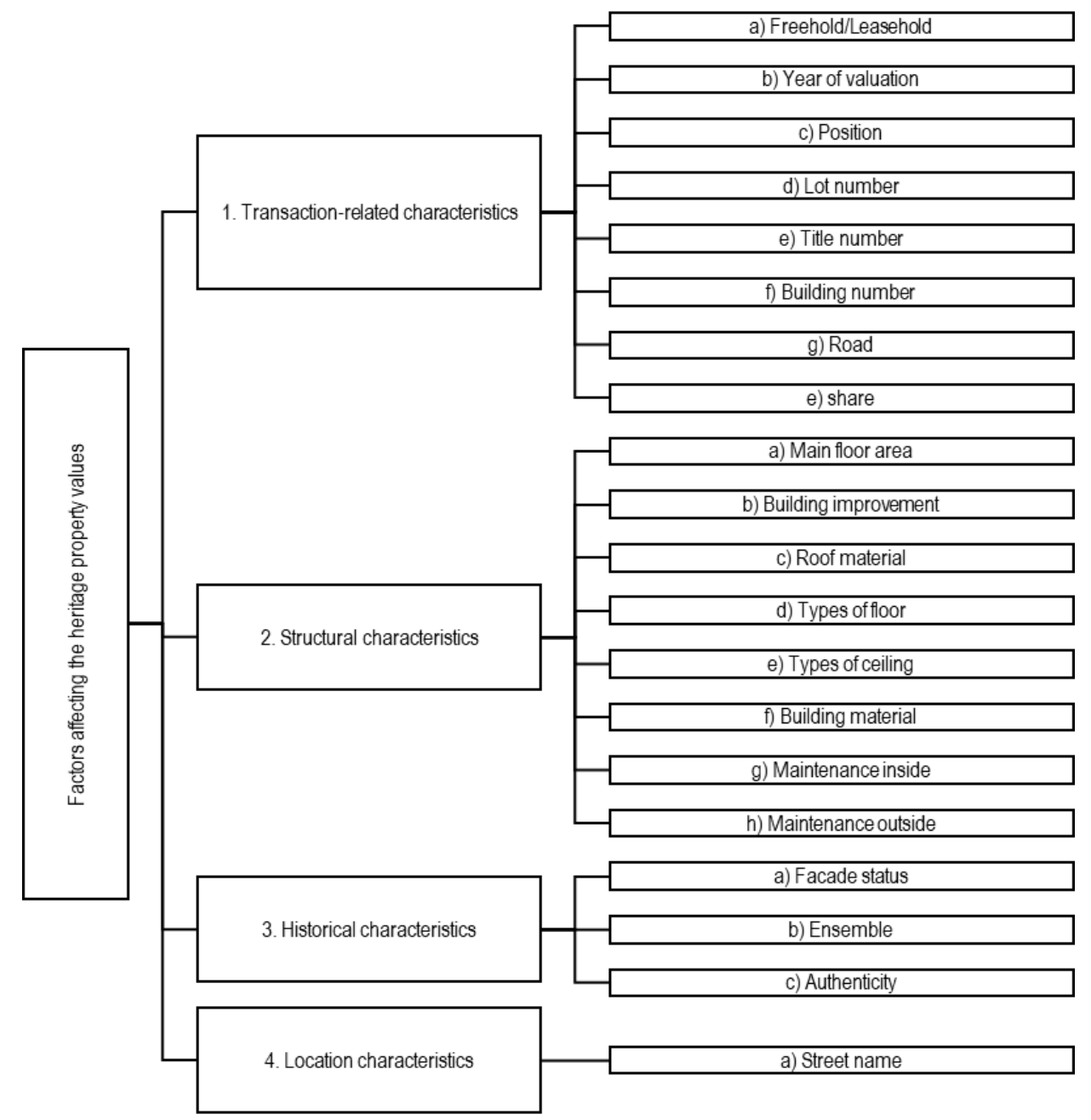

Fig. 2: Factors Affecting Heritage Property Values Source: Adapted from Ruijgrok (2006)

\subsection{The methods used in valuing heritage property}

The aims of this study are to determine the market value of private heritage property using statistical method of analysis considering the issue of limited market evidence. Figure 3 summaries the previous study on the methods used in valuing heritage property. 


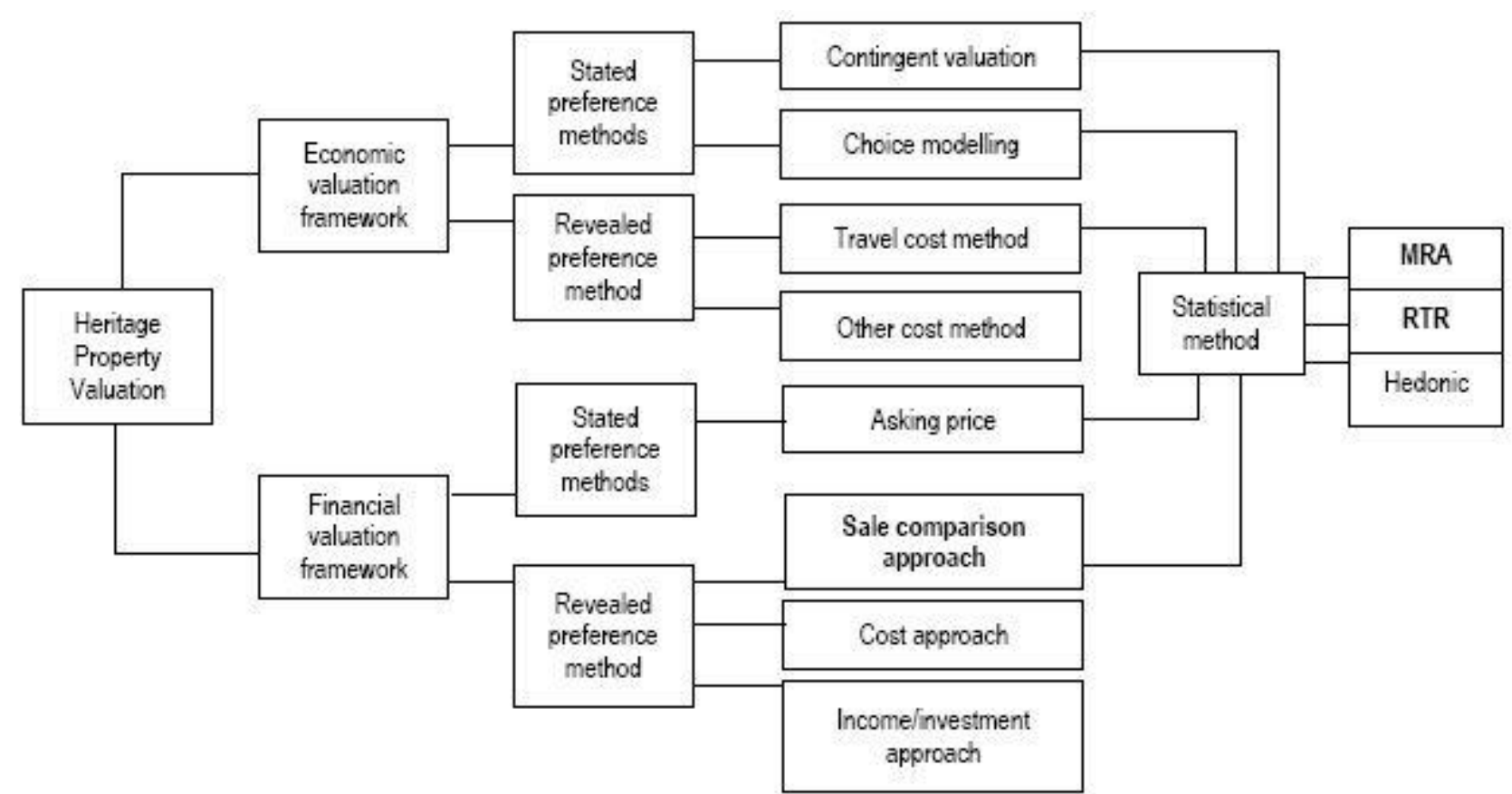

Fig. 3: The methods in literature that are used in valuing heritage property Source: Authors

According to International Valuation Standards (2011), there are three principle valuation approaches used in heritage property valuation. The approaches are sale comparison approach, cost approach and income approach. According to the study conducted by the main author in previous paper Mohamad et al. (2015) the sale comparison approach is the most preferable method used by Malaysian's valuers in valuing private heritage property. The valuers recognized the limitations of the comparison method but there is no better alternative available to them. Therefore, the aims of this study are to test the applicability of statistical methods of MRA and RTR for assessing heritage property values.

It is a real challenge when dealing with old property. The deteriorating condition of the heritage property and archaic services may affect the value of heritage property. Besides that, the heritage property is protected by a policy and the restriction may affect the values and its marketability. Often, the restriction may drop. The transaction of heritage property market is limited. Hence, it is very difficult to apply the MRA because this method is suitable for large data and errors will exist. Therefore, we need an appropriate method to be used in measuring heritage property that can capturing thin market issue. Cronan et al. (1986) and Mohamad (2012) have argued about the ability of MRA in valuing residential property values with small sample. Therefore, the authors have suggested the use of RTR in order to overcome the thin market (small sample) issue. Furthermore, this RTR can overcome the non-normal distribution problem and outliers. The value estimates produced by the RTR is more accurate and more successfully in statistical performance.

MRA is an extension of the sale comparison method of valuation. The former explains and evaluates the relationship between variables and other variables. The variables in MRA are divided into dependent variables $Y$ (property price) and independent variables $\mathrm{X}$ (property characteristics). The general expression of MRA equation can be written as follows:

$$
\mathrm{Y}=b_{0}+b_{1} x_{1}+b_{2} x_{2}+\ldots \ldots \ldots \ldots . . . . b_{n} x_{n}
$$

where $Y=$ market value (dependent variable), $x_{1}, x_{2}, \ldots . ., x_{n}=$ independent variables; $b_{1}, b_{2}, \ldots \ldots ., b_{n}=$ regression coefficients: $b_{0}=$ constant; and $n=$ total number of variables specified in the model.

RTR is a simple procedure whereby the data are arranged in a corresponding order, for example, rank 1 for the largest observation and rank $n$ for the smallest observation. Iman (1974) and Montgomery (2008) stated that RTR is a robust and powerful tool to be used in hypothesis testing. This technique is widely used in many fields of study but has yet to be explored in heritage property valuation. The RTR procedure considers the theory of property valuation to rank comparable properties from highest to lowest (Cronan et al. 1986). The regression equation is as follows:

$$
\begin{aligned}
& \mathfrak{R}(\mathrm{Y})=(n+1) / 2+\beta_{1}(R(x)-(n+1) / 2 \\
& \left.R(x)_{(n+1)}=R\left(x_{(i)}\right)+\left[R\left(x_{(i+1)}\right)-R\left(x_{(i)}\right)\right] *\left[x_{(n+1)}-x_{(1)}\right) /\left(x_{(i+1)}-x_{(i)}\right)\right] \\
& Y_{(n+1)}=Y_{(i)}+\left[Y_{(i+1)}-Y_{(i)}\right] *\left[\Re\left(Y_{(n+1)}\right)-R\left(Y_{(i+1)}-R\left(Y_{(n)}\right)\right)\right]
\end{aligned}
$$

where equation (1) refers to RTR; equation (2) refers to the ranking of the independent variables; and equation (3) refers to ranking of dependent variable. The application of RTR takes same steps as MRA. Nevertheless, the difference between the two methods is that 
the RTR method is applied in rank form where all continuous variables are converted into rank, including the dependent variables. The estimated values are also put in a rank form and will be converted to normal values.

\subsection{Research Methodology}

The secondary data on property transactions for this paper were collected in digital form from Kota Bharu State Valuation and Property Services Department (VPSD Kota Bharu). The data contained record of commercial property transactions in Kota Bharu, Kelantan from 2004 to 2014.

The data used have been provided by VPSD Kota Bharu and concerned prewar shophouse transactions from 2004 to 2014. Over 11 years, only 25 (19 in-sample and 6 out-sample) transactions involved the prewar shophouse. Comparing with previous studies by Lazrak et al. (2014), the total transaction data used for the study was 51 for a period of 22 years from 1985 to 2014. This paper involved a period of 11 years from 2004 to 2014 with total transaction of 25 . Therefore, the observation was still valid as heritage property is classified as special property with limited transactions. The VPSD Kota Bharu has provided data on numerous transactional and structural characteristics of each transaction. The data were enriched with information obtained from Kota Bharu Municipal Council (MPKB) and site inspections especially in order to improve the data regarding historical characteristics.

The registered sale price was the actual price paid for the shophouse. Thus, the price data used in this study was transaction price. However, during filtration process, only arm's length transaction is considered. Some additional transaction-related characteristics were used as control variables such as the year of the transaction taken. The structural characteristics include floor area, land area, building improvement, building material, maintenance of the building, type of ceiling. Historical characteristics included façade status, architectural style, ensemble and authenticity.

Table 2 shows the filtering process of the original set of data from 2004 to 2014 in which only 25 observations (prewar shophouse) remained for this study. The data were examined for completeness and usefulness to develop the MRA and RTR models. There were four steps involved in discarding 'problematic' data, namely; 1) removing all incomplete data such as those without information on land area, floor area, tenure, selling price and others. This study employed enter regression to run the analysis using IBM SPSS statistic. Table 3 shows the descriptive statistics of the final dataset used in this study.

Table 2. A record of data cleaning process

\begin{tabular}{|c|c|c|}
\hline No & Notes & Number of records left \\
\hline 1. & $\begin{array}{l}\text { Original data from 2004-2014 for commercial property received from } \\
\text { VPSD Kota Bharu }\end{array}$ & 893 \\
\hline 2. & Excluding non shophouse property & 617 \\
\hline 3. & Excluding plot status & 406 \\
\hline 4. & Excluding incomplete and redundant data & 365 \\
\hline 5. & $\begin{array}{l}\text { Excluding property transaction record based on street's name. Choose } \\
\text { only; Jalan Ismail, Jalan Temenggong, Jalan Che Su, Jalan Dato Pati, } \\
\text { Jalan Hilir Pasar, Jalan Gajah Mati, Jalan Hulu Pasar, Jalan Ismail, } \\
\text { Jalan Padang Garong, Jalan Pos Office Lama, Jalan Suara Muda, Jalan } \\
\text { Tg Putera Semerak, Jalan Tok Hakim, Jalan Maju (includes Grade I, II } \\
\text { and III of heritage property) }\end{array}$ & 70 \\
\hline 6. & Excluding records with share & 51 \\
\hline 7. & $\begin{array}{l}\text { Excluding property transaction other than Jalan Temenggong, Jalan Tok } \\
\text { Hakim, Jalan Ismail, Jalan Hilir Pasar and Jalan Hulu Pasar (only these } \\
\text { five locations were chosen) }\end{array}$ & 47 \\
\hline 8. & Excluding records with incomplete or confusing information & 25 \\
\hline
\end{tabular}

Table 3. Descriptive statistics of final dataset

\begin{tabular}{|c|c|c|c|c|c|c|c|}
\hline No & Label/Code & Definition & $\begin{array}{l}\text { Type of } \\
\text { variables }\end{array}$ & Min & Max & Mean & Std. Dev \\
\hline 1. & Price & Transaction price & continuous & 250000 & 1050000 & 653157.89 & 198243.751 \\
\hline 2. & IgPrice & Transaction price transformed into log & continuous & 5.40 & 6.02 & 5.7936 & 0.14631 \\
\hline 3. & Rprice & Transaction price transformed into rank & continuous & 1.00 & 19.00 & 10.0000 & 5.59017 \\
\hline 4. & IgR_price & Transaction price transformed into log and rank & continuous & 0.00 & 1.28 & 0.9007 & .034838 \\
\hline 5. & Transaction_length & $\begin{array}{l}Y 04=1, Y 05=2, Y 06=3, Y 07=4, Y 08=5, Y 09=6, \\
Y 10=7, Y 11=8, Y 13=9\end{array}$ & category & 1 & 9 & 4.37 & 2.692 \\
\hline 6. & Road & $\begin{array}{l}\text { Equals I if building located at JIn Temenggong } \\
\text { and } 0 \text { if land located other than JIn Temenggong }\end{array}$ & dummy & 0 & 1 & 0.58 & 0.507 \\
\hline 7. & LA & Size of land area & continuous & 118.912 & 184.00 & 132.08911 & 16.502171 \\
\hline 8. & $\lg L A$ & Land area transformed into log & continuous & 2.08 & 2.26 & 2.1181 & 0.04891 \\
\hline 9. & R_LA & Land area transformed into rank & continuous & 1.00 & 18.50 & 10.0000 & 5.61496 \\
\hline 10. & $\lg \bar{R} \_L A$ & Land area transformed into log and rank & continuous & 0.00 & 1.27 & 0.8995 & 0.35038 \\
\hline 11. & MFA & Size of living space of the building & continuous & 149.57 & 595.32 & 243.4816 & 109.99932 \\
\hline 12. & $\operatorname{IgMFA}$ & Main floor area transformed into log & continuous & 2.17 & 2.77 & 2.3563 & 0.15398 \\
\hline 13. & R_MFA & Main floor area transformed into rank & continuous & 1.00 & 19.00 & 10.0000 & 5.61991 \\
\hline 14. & $\lg R \_M F A$ & Main floor area transformed into log and rank & continuous & 0.00 & 1.28 & 0.8994 & 0.35052 \\
\hline 15. & Freehold & Equals 1 if land is freehold and 0 if land is & Dummy & 0 & 1 & 0.95 & 0.229 \\
\hline
\end{tabular}




\begin{tabular}{|c|c|c|c|c|c|c|c|}
\hline No & Label/Code & Definition & $\begin{array}{l}\text { Type of } \\
\text { variables }\end{array}$ & Min & Max & Mean & Std. Dev \\
\hline 16. & Position & $\begin{array}{l}\text { Category variable: } \\
\text { Middle }=2 \text {, end=1 }\end{array}$ & category & 1 & 2 & 1.79 & 0.419 \\
\hline 17. & Basic_building_component & $\begin{array}{l}\text { (Total scoring variable of roof, floor and ceilling): } \\
\text { Roof (Slate=1, asbestos=2, concreate=3, zink=4) } \\
\text { Floor (Simen=1, tiles=2, old tiles=3, pergo } \\
\text { syntetic=4) } \\
\text { Ceilling (Asbestos=1, concreate=2) }\end{array}$ & category & 3 & 7 & 5.00 & 1.414 \\
\hline 18. & Building & $\begin{array}{l}\text { 1=wood_brick } \\
2=\text { brick }\end{array}$ & category & 1 & 2 & 1.89 & 0.315 \\
\hline 19. & Maintenance & $\begin{array}{l}\text { (Total scoring of maintenance inside and outside): } \\
\text { inside ( } 1=\text { not maintain, } 2=\text { maintain) } \\
\text { outside ( } 1=\text { not maintain, } 2=\text { maintain) }\end{array}$ & category & 2 & 4 & 3.74 & 0.653 \\
\hline 20. & *Composite_historical_charac & $\begin{array}{l}\text { (Total scoring of façade, architectural style, } \\
\text { ensemble and authenticity): } \\
\text { Façade (equals } 1 \text { if maintain and } 0 \text { if total } \\
\text { changes) } \\
\text { Architectural style ( equals } 1 \text { if functionalistic and } \\
0 \text { if not functionalistic) } \\
\text { Ensemble ( In full harmony with surroundings = } 1 \text {, } \\
\text { partially in harmony }=2 \text {, disharmony }=3 \text { ) } \\
\text { Authenticity ( If all three were in tact }=1 \text {, if one or } \\
\text { two of the three were in tact }=2 \text {, none were in tact } \\
=3 \text { ) }\end{array}$ & category & 5 & 10 & 8.32 & 1.250 \\
\hline
\end{tabular}

\subsection{Results and Discussions}

This section evaluates and estimates the value of the pre-war shophouses in Kota Bharu, Kelantan, Malaysia, as a case study by using MRA and RTR.

\subsection{Pairwise correlation matrix}

Multicollinearity is the assumption made by using regression techniques i.e MRA and RTR on explanatory variables (factors affecting the values of heritage property) to see if the variables are correlated or not correlated to each other (Brooks and Tsolacos 2010). If the results show no relationships between the explanatory variables (no correlation), they would be said to be statistically independent to another. If the variables are high correlated, it will lead to unreliable and unstable estimates of regression coefficients. Most of the researchers know that multicollinearity is not a good thing. Table 4 shows the correlation indices of the original variables in order to indicate the multicollinearity among them. The results reveal that there are no variables that have collinearity index above 0.8 . According to Suriatini Ismail (2005), there are no guidelines on which variables are causing a problem when a pair of variables is shown to have high collinearity index above 0.8 . This study also relies on the VIF values of the independent variables as a procedure for double check. The following subsection discusses the VIF values.

Table 4. Correlation indices

\begin{tabular}{|c|c|c|c|c|c|c|c|c|c|c|c|c|}
\hline & & Road & $\begin{array}{l}\text { Transaction } \\
\text { length }\end{array}$ & Freehold & $\overline{L A}$ & MFA & Position & $\begin{array}{l}\text { Basic_ } \\
\text { building_ } \\
\text { component }\end{array}$ & Building & Maintenance & $\begin{array}{l}\text { Composite_ } \\
\text { historical_ } \\
\text { charac }\end{array}$ & Price \\
\hline \multirow[t]{2}{*}{ Road } & $\begin{array}{l}\text { Pearson } \\
\text { correlation }\end{array}$ & 1 & .201 & .276 & -.013 & -.272 & -179 & .077 & -.293 & .318 & .397 & .445 \\
\hline & $\begin{array}{l}\text { Sig. (2- } \\
\text { tailed) }\end{array}$ & & .409 & .252 & .958 & .259 & .464 & .753 & .224 & .185 & .093 & .056 \\
\hline \multirow[t]{2}{*}{$\begin{array}{l}\text { Transaction_ } \\
\text { length }\end{array}$} & $\begin{array}{l}\text { Pearson } \\
\text { correlation }\end{array}$ & .201 & 1 & .213 & -.083 & -.112 & -.223 & .015 & .114 & .216 & .393 & .370 \\
\hline & $\begin{array}{l}\text { Sig. }(2- \\
\text { tailed) }\end{array}$ & .409 & & .381 & .737 & .648 & .359 & .953 & .643 & .374 & .096 & .118 \\
\hline \multirow[t]{2}{*}{ Freehold } & $\begin{array}{l}\text { Pearson } \\
\text { correlation }\end{array}$ & .276 & .213 & 1 & .085 & -.003 & -.122 & 0.000 & -.081 & -.098 & .061 & .285 \\
\hline & $\begin{array}{l}\text { Sig. (2- } \\
\text { tailed) }\end{array}$ & .252 & .381 & & .730 & .991 & .620 & 1.000 & .742 & .691 & .803 & .237 \\
\hline \multirow[t]{2}{*}{ LA } & $\begin{array}{l}\text { Pearson } \\
\text { correlation }\end{array}$ & -.013 & -.083 & .085 & 1 & $.770^{* *}$ & .292 & .365 & -.442 & .205 & .015 & $.551^{*}$ \\
\hline & $\begin{array}{l}\text { Sig. (2- } \\
\text { tailed) }\end{array}$ & .958 & .737 & .730 & & .000 & .226 & .124 & .058 & .400 & .952 & .015 \\
\hline \multirow[t]{2}{*}{ MFA } & $\begin{array}{l}\text { Pearson } \\
\text { correlation }\end{array}$ & -.272 & -.112 & -.003 & $.770^{* *}$ & 1 & .207 & .411 & -.319 & .118 & -.275 & .267 \\
\hline & $\begin{array}{l}\text { Sig. (2- } \\
\text { tailed) }\end{array}$ & .259 & .648 & .991 & .000 & & .394 & .081 & .183 & .630 & .254 & .269 \\
\hline \multirow[t]{2}{*}{ Position } & $\begin{array}{l}\text { Pearson } \\
\text { correlation }\end{array}$ & -.179 & -.223 & -.122 & .292 & .207 & 1 & 0.000 & -.177 & -.214 & .240 & .018 \\
\hline & Sig. (2- & .464 & .359 & .620 & .226 & .394 & & 1.000 & .468 & .380 & .322 & .941 \\
\hline
\end{tabular}




\begin{tabular}{|c|c|c|c|c|c|c|c|c|c|c|c|c|}
\hline & & Road & $\begin{array}{l}\text { Transaction_ } \\
\text { length }\end{array}$ & Freehold & LA & MFA & Position & $\begin{array}{l}\text { Basic_ } \\
\text { building__ } \\
\text { component }\end{array}$ & Building & Maintenance & $\begin{array}{l}\text { Composite_ } \\
\text { historical_- } \\
\text { charac }\end{array}$ & Price \\
\hline & tailed) & & & & & & & & & & & \\
\hline \multirow{2}{*}{$\begin{array}{l}\text { Basic_- } \\
\text { building_- } \\
\text { component }\end{array}$} & $\begin{array}{l}\text { Pearson } \\
\text { correlation }\end{array}$ & .077 & .015 & 0.000 & .365 & .411 & 0.000 & 1 & 0.000 & $.541^{*}$ & -283 & .250 \\
\hline & $\begin{array}{l}\text { Sig. (2- } \\
\text { tailed) }\end{array}$ & .753 & .953 & 1.000 & .124 & .081 & 1.000 & & 1.000 & .017 & .240 & .303 \\
\hline \multirow[t]{2}{*}{ Building } & $\begin{array}{l}\text { Pearson } \\
\text { correlation }\end{array}$ & -.293 & .114 & -.081 & -.442 & -.319 & -.177 & 0.000 & 1 & .128 & -193.- & .217 \\
\hline & $\begin{array}{l}\text { Sig. (2- } \\
\text { tailed) }\end{array}$ & .224 & .643 & .742 & .058 & .183 & .468 & 1.000 & & .602 & .429 & .373 \\
\hline \multirow[t]{2}{*}{ Maintenance } & $\begin{array}{l}\text { Pearson } \\
\text { correlation }\end{array}$ & .318 & .216 & -.098 & .205 & .118 & -.214 & $.541^{\star}$ & .128 & 1 & -.165 & .320 \\
\hline & $\begin{array}{l}\text { Sig. (2- } \\
\text { tailed) }\end{array}$ & .185 & .374 & .691 & .400 & .630 & .380 & .017 & .602 & & .500 & .182 \\
\hline \multirow[t]{2}{*}{$\begin{array}{l}\text { Compoite_ } \\
\text { historical_ } \\
\text { charac }\end{array}$} & $\begin{array}{l}\text { Pearson } \\
\text { correlation }\end{array}$ & .397 & .393 & .061 & .015 & -.275 & .240 & -.283 & -.193 & -.165 & 1 & .218 \\
\hline & $\begin{array}{l}\text { Sig. (2- } \\
\text { tailed) }\end{array}$ & .093 & .096 & .803 & .952 & .254 & .322 & .240 & .429 & .500 & & .370 \\
\hline \multirow[t]{2}{*}{ Price } & $\begin{array}{l}\text { Pearson } \\
\text { correlation }\end{array}$ & .445 & .370 & .285 & $.551^{*}$ & .267 & -.018 & .250 & -.217 & .320 & .218 & 1 \\
\hline & $\begin{array}{l}\text { Sig. (2- } \\
\text { tailed) }\end{array}$ & .056 & .118 & .237 & .015 & .269 & .941 & .303 & .373 & .182 & .370 & \\
\hline
\end{tabular}

4.2 Variance inflation factors (VIF)

VIF is a popular method used to detect multicollinearity. There are two opinions in indicating high multicollinearity using VIF. First, O'brien (2007) stated that a VIF value below 10 indicates low multicollinearity, and Des Rosiers et al. (2000) and Thériault et al. (2003) stated that a VIF value below 5 indicates low multicollinearity. However, according to Suriatini (2005), there is no theoretical basis for choosing which VIF value (either below 10 or below 5) in order to detect multicollinearity. Therefore, this study adopts the value of 10 in detecting suspicious variables regarding multicollinearity. The VIF value of each variable is shown in Table 5 and Table 6 .

\subsection{Choice of functional form}

Commonly, the generic features of a real-estate market are nonlinearity (Moro et al. 2013; Wilson 1993) because the property market is heterogeneous; the price of a real-estate property is influenced by many variables. Therefore, in developing the MRA and RTR, this study considered different functional forms, the purpose being to choose which functional form fits the data in hand best in order to explain the characteristics of the data. This study used three types of functional forms: linear, semi-log, and log-log.

The enter regression involved a dataset of 19 (in-sample) observations with prewar shophouse prices as the dependent variables and 10 independent variables. The independent variables comprise the following 2 dummy variables (Road and Freehold), 2 continuous variables (LA and MFA) and 6 category variables (Position, Basic_building_component, Transaction_length, Building, Maintenance, Composite_historical_charac). The following subsection presents the result of linear, semi-log and log-log functional forms of the MRA and RTR models.

\subsection{The performance of three functional form}

The linear, semi-log and log-log functional forms of the MRA and RTR models that have been estimated are shown in Table 5 and Table 6. For MRA model, the linear functional form has the highest Adjusted $\mathrm{R}^{2}$ of $23.2 \%$ compared to the other two (-1.1\% for semi$\log$ and $-2.6 \%$ for log-log). As for the RTR model, log-log functional forms have the highest Adjusted $\mathrm{R}^{2}$ of $67.1 \%$ compared to the other two (51.8\% for linear and $65.9 \%$ for semi-log).

The highest Adjusted $\mathrm{R}^{2}$ for MRA is linear functional form with $23.2 \%$ and for RTR log-log have the highest Adjusted $\mathrm{R}^{2}$ of $67.1 \%$. High Adjusted $R^{2}$ is quite normal in time-series data. However, the data set of this study spanned for about 10 years $=120$ months $=40$ quarters. Property prices may have changed over a range of values during that period. In addition, high Adjusted $\mathrm{R}^{2}$ with a few variables and small sample can be indicative of serial correlation. Therefore, can be concluded that, the value of Adjusted R² for MRA and RTR of this study are acceptable.

Table 5. The linear, semi-log and log-log functional form of MRA

\begin{tabular}{llllllll}
\hline \multicolumn{2}{l}{ Linear functional form of MRA } & \multicolumn{2}{l}{$l$} \\
\hline \multicolumn{2}{c}{ Coefficients } & Unstandardized Coefficients & & & \\
& & B & Std. Error & $\mathrm{t}$ & Sig & VIF \\
\hline 1 & (Constant) & -661530.147 & 721892.658 & -.916 & 0.386 & \\
2 & Road & 190315.831 & 127158.883 & 1.497 & 0.173 & 2.483 \\
3 & Transaction_length & 29043.004 & 20157.936 & 1.441 & 0.188 & 1.757
\end{tabular}




\begin{tabular}{|c|c|c|c|c|c|c|}
\hline \multicolumn{7}{|c|}{ Linear functional form of MRA } \\
\hline & \multirow[t]{2}{*}{ Coefficients } & \multicolumn{5}{|c|}{ Unstandardized Coefficients } \\
\hline & & $\mathrm{B}$ & Std. Error & $\mathrm{t}$ & Sig & VIF \\
\hline 4 & Freehold & 9108.319 & 208873.369 & 0.044 & 0.966 & 1.370 \\
\hline 5 & LA & 9861.108 & 4777.892 & 2.064 & 0.073 & 3.709 \\
\hline 6 & MFA & -291.087 & 720.777 & -0.404 & 0.697 & 3.751 \\
\hline 7 & Position & 1087.881 & 119621.551 & 0.009 & 0.993 & 1.498 \\
\hline 8 & Basic_building_component & -2601.383 & 38879.955 & -0.067 & 0.948 & 1.804 \\
\hline 9 & Building & 109050.780 & 173319.633 & 0.629 & 0.547 & 1.782 \\
\hline 10 & Maintenance & -33090.821 & 96958.716 & -0.341 & 0.742 & 2.395 \\
\hline \multirow[t]{7}{*}{11} & Composite_historical_chrac & -28208.233 & 52728.036 & -0.535 & 0.607 & 2.590 \\
\hline & \multicolumn{6}{|l|}{ a Dependent Variable: Price } \\
\hline & Adjusted $\mathrm{R}^{2}$ & \multicolumn{5}{|l|}{$23.2 \%$} \\
\hline & SE & \multicolumn{5}{|l|}{173683.513} \\
\hline & $\mathrm{F}$ & \multicolumn{5}{|l|}{1.545} \\
\hline & $\mathrm{N}$ & \multicolumn{5}{|l|}{19} \\
\hline & MSE & \multicolumn{5}{|l|}{$4.661 \mathrm{E}+10$} \\
\hline \multicolumn{7}{|c|}{ Semi-log functional form of MRA } \\
\hline \multirow{2}{*}{\multicolumn{2}{|c|}{ Coefficients }} & \multicolumn{5}{|c|}{ Unstandardized Coefficients } \\
\hline & & $\mathrm{B}$ & Std. Error & $\mathrm{t}$ & Sig & VIF \\
\hline 1 & (Constant) & 5.126 & 0.611 & 8.384 & 0.000 & \\
\hline 2 & Road & 0.135 & 0.108 & 1.253 & 0.245 & 2.483 \\
\hline 3 & Transaction_length & 0.026 & 0.017 & 1.530 & 0.164 & 1.757 \\
\hline 4 & Freehold & -0.002 & 0.177 & -0.010 & 0.992 & 1.370 \\
\hline 5 & LA & 0.007 & 0.004 & 1.715 & 0.125 & 3.709 \\
\hline 6 & MFA & 0.000 & 0.001 & -0.391 & 0.706 & 3.751 \\
\hline 7 & Position & -0.004 & 0.101 & -0.040 & 0.969 & 1.498 \\
\hline 8 & Basic_building_component & -0.001 & 0.033 & -0.045 & 0.965 & 1.804 \\
\hline 9 & Building & 0.077 & 0.147 & 0.525 & 0.614 & 1.782 \\
\hline 10 & Maintenance & -0.045 & 0.082 & -0.549 & 0.598 & 2.395 \\
\hline \multirow[t]{7}{*}{11} & Composite_historical_charac & -0.041 & 0.045 & -0.927 & 0.381 & 2.590 \\
\hline & \multicolumn{6}{|l|}{ a Dependent Variable: IgPrice } \\
\hline & Adjusted R2 & \multicolumn{5}{|l|}{$-1.1 \%$} \\
\hline & SE & \multirow{2}{*}{\multicolumn{5}{|c|}{$\begin{array}{l}0.14709 \\
0.981\end{array}$}} \\
\hline & $\mathrm{F}$ & & & & & \\
\hline & $\mathrm{N}$ & \multicolumn{5}{|l|}{19} \\
\hline & MSE & \multicolumn{5}{|l|}{0.021} \\
\hline \multicolumn{7}{|c|}{ Log-log functional form of MRA } \\
\hline \multirow{2}{*}{\multicolumn{2}{|c|}{ Coefficients }} & \multicolumn{5}{|c|}{ Unstandardized Coefficients } \\
\hline & & $\mathrm{B}$ & Std. Error & $t$ & Sig & VIF \\
\hline 1 & (Constant) & 1.680 & 2.123 & 0.791 & 0.452 & \\
\hline 2 & Road & 0.130 & 0.107 & 1.216 & 0.259 & 2.417 \\
\hline 3 & Transaction_length & 0.025 & 0.017 & 1.474 & 0.179 & 1.733 \\
\hline 4 & Freehold & -0.001 & 0.180 & -0.005 & 0.996 & 1.392 \\
\hline 5 & $\lg L A$ & 2.170 & 1.382 & 1.570 & 0.155 & 3.747 \\
\hline 6 & IgMFA & -0.121 & 0.468 & -0.259 & 0.802 & 4.250 \\
\hline 7 & Position & -0.013 & 0.103 & -0128 & 0.901 & 1.523 \\
\hline 8 & Basic_building_component & -0.002 & 0.032 & -0.056 & 0.957 & 1.707 \\
\hline
\end{tabular}




\begin{tabular}{|c|c|c|c|c|c|c|}
\hline \multicolumn{7}{|c|}{ Linear functional form of MRA } \\
\hline & \multirow[t]{2}{*}{ Coefficients } & \multicolumn{5}{|c|}{ Unstandardized Coefficients } \\
\hline & & $\mathrm{B}$ & Std. Error & $t$ & Sig & VIF \\
\hline 9 & Building & 0.057 & 0.152 & 0.371 & 0.720 & 1.894 \\
\hline 10 & Maintenance & -0.041 & 0.082 & -0.501 & 0.630 & 2.360 \\
\hline \multirow[t]{7}{*}{11} & Composite_historical_charac & -0.036 & 0.046 & -0.784 & 0.455 & 2.750 \\
\hline & a Dependent Variable: IgPrice & & & & & \\
\hline & Adjusted R2 & $-2.6 \%$ & & & & \\
\hline & SE & 0.14818 & & & & \\
\hline & $\mathrm{F}$ & 0.955 & & & & \\
\hline & $\mathrm{N}$ & 19 & & & & \\
\hline & MSE & 0.021 & & & & \\
\hline
\end{tabular}

Table 6. The linear, semi-log and log-log functional form of RTR

\begin{tabular}{|c|c|c|c|c|c|c|}
\hline \multicolumn{7}{|c|}{ Linear functional form of RTR } \\
\hline & \multirow[t]{2}{*}{ Coefficients } & \multicolumn{5}{|c|}{ Unstandardized Coefficients } \\
\hline & & \multirow{2}{*}{$\frac{B}{22.224}$} & \multirow{2}{*}{$\begin{array}{l}\text { Std. Error } \\
18.600\end{array}$} & \multirow{2}{*}{$\frac{t}{1.195}$} & \multirow{2}{*}{$\frac{\text { Sig }}{0.266}$} & \multirow[t]{2}{*}{ VIF } \\
\hline 1 & (Constant) & & & & & \\
\hline 2 & Road & -2.438 & 2.727 & -0.894 & 0.397 & 2.288 \\
\hline 3 & Transaction_length & -0.908 & 0.442 & -2.054 & 0.074 & 1.691 \\
\hline 4 & Freehold & -5.000 & 4.704 & -1.063 & 0.319 & 1.392 \\
\hline 5 & Position & 2.626 & 3.041 & 0.863 & 0.413 & 1.939 \\
\hline 6 & Basic_building_component & -1.136 & 0.823 & -1.380 & 0.205 & 1.620 \\
\hline 7 & Building & -0.852 & 4.390 & -0.194 & 0.851 & 2.290 \\
\hline 8 & Maintenance & 0.600 & 2.141 & 0.280 & 0.786 & 2.340 \\
\hline 9 & Composite_historical_charac & -1.044 & 1.203 & -0.867 & 0.411 & 2.702 \\
\hline 10 & R_LA & 0.553 & 0.247 & 2.234 & 0.056 & 2.307 \\
\hline 11 & R_MFA & 0.139 & 0.294 & 0.473 & 0.649 & 3.270 \\
\hline \multicolumn{7}{|c|}{ a Dependent Variable: R_Price } \\
\hline & Adjusted $\mathrm{R}^{2}$ & \multicolumn{5}{|l|}{$51.8 \%$} \\
\hline & SE & \multicolumn{5}{|l|}{3.88054} \\
\hline & $\mathrm{F}$ & \multicolumn{5}{|l|}{2.935} \\
\hline & $\mathrm{N}$ & \multicolumn{5}{|l|}{19} \\
\hline & MSE & \multicolumn{5}{|l|}{44.203} \\
\hline \multicolumn{7}{|c|}{ Semi-log functional form of RTR } \\
\hline \multirow{2}{*}{\multicolumn{2}{|c|}{ Coefficients }} & \multicolumn{5}{|c|}{ Unstandardized Coefficients } \\
\hline & & $\mathrm{B}$ & Std. Error & $t$ & Sig & VIF \\
\hline 1 & (Constant) & 1.517 & 0.975 & 1.556 & 0.158 & \\
\hline 2 & Road & -0.015 & 0.143 & -0.108 & 0.917 & 2.288 \\
\hline 3 & Transaction_length & -0.045 & 0.023 & -1.958 & 0.086 & 1.691 \\
\hline 4 & Freehold & -0.212 & 0.247 & -0.859 & 0.415 & 1.392 \\
\hline 5 & Position & 0.167 & 0.159 & 1.047 & 0.326 & 1.939 \\
\hline 6 & Basic_building_component & -0.048 & 0.043 & -1.109 & 0.300 & 1.620 \\
\hline 7 & Building & 0.242 & 0.230 & 1.050 & 0.324 & 2.290 \\
\hline 8 & Maintenance & -0.029 & 0.112 & -0.261 & 0.801 & 2.340 \\
\hline 9 & Composite_historical_charac & -0.126 & 0.063 & -2.005 & 0.080 & 2.702 \\
\hline 10 & R_LA & 0.041 & 0.013 & 3.125 & 0.014 & 2.307 \\
\hline 11 & R_MFA & 0.003 & 0.015 & 0.191 & 0.853 & 3.270 \\
\hline
\end{tabular}




\begin{tabular}{|c|c|c|c|c|c|c|}
\hline \multicolumn{7}{|c|}{ a Dependent Variable: IgR_Price } \\
\hline & Adjusted $R^{2}$ & \multicolumn{5}{|l|}{$65.9 \%$} \\
\hline & SE & \multicolumn{5}{|l|}{$\begin{array}{l}0.20341 \\
4.480\end{array}$} \\
\hline & $\mathrm{F}$ & \\
\hline & $\mathrm{N}$ & \multicolumn{5}{|l|}{19} \\
\hline & MSE & \multicolumn{5}{|l|}{0.185} \\
\hline \multicolumn{7}{|c|}{ Log-log functional form of RTR } \\
\hline \multirow{2}{*}{\multicolumn{2}{|c|}{ Coefficients }} & \multicolumn{5}{|c|}{ Unstandardized Coefficients } \\
\hline & & B & Std. Error & $t$ & Sig & VIF \\
\hline 1 & (Constant) & 1.037 & 0.882 & 1.176 & 0.274 & \\
\hline 2 & Road & -0.149 & 0.140 & -1.063 & 0.319 & 2.270 \\
\hline 3 & Transaction_length & -0.044 & 0.023 & -1.947 & 0.087 & 1.697 \\
\hline 4 & Freehold & -0.063 & 0.244 & -0.260 & 0.801 & 1.410 \\
\hline 5 & Position & 0.105 & 0.145 & 0.725 & 0.489 & 1.674 \\
\hline 6 & Basic_building_component & -0.022 & 0.044 & -0.512 & 0.623 & 1.720 \\
\hline 7 & Building & 0.054 & 0.200 & 0.270 & 0.794 & 1.802 \\
\hline 8 & Maintenance & 0.009 & 0.114 & 0.078 & 0.940 & 2.521 \\
\hline 9 & Composite_historical_charac & -0.075 & 0.061 & -1.237 & 0.251 & 2.614 \\
\hline 10 & IgR_LA & 0.732 & 0.218 & 3.354 & 0.010 & 2.641 \\
\hline \multirow[t]{7}{*}{11} & IgR_MFA & -0.046 & 0.245 & -0.189 & 0.8555 & 3.342 \\
\hline & \multicolumn{6}{|l|}{ a Dependent Variable: IgR_Price } \\
\hline & Adjusted R² & \multicolumn{5}{|l|}{$67.1 \%$} \\
\hline & SE & \multicolumn{5}{|l|}{0.19970} \\
\hline & $\mathrm{F}$ & \multicolumn{5}{|l|}{4.678} \\
\hline & $\mathrm{N}$ & \multicolumn{5}{|l|}{19} \\
\hline & MSE & \multicolumn{5}{|l|}{0.187} \\
\hline
\end{tabular}

\subsection{The best functional form of MRA and RTR models}

Based on the functional form selection, the best functional forms are linear of MRA and log-log of RTR models. Hence, this section applies the selected models into observation data to estimate the predictive value for both models. The equations of linear MRA and $\log -\log$ RTR are:

The linear MRA model is given by:

MV $=661530.148+$ Road $^{*} 190315.831+$ Transaction_length ${ }^{*} 29043.004+$ Freehold*9108.319+LA*9861.108+MFA*-

291.087+Position*1087.881+Basic_building_component*-2601.383+Building*109050.780+Maintenance*-

33090.821+Composite_historical_charac*-28208.233

Where;

MV is referring to market value

Road is referring to location of shophouse heritage property

Transaction_length is referring to year of transaction transformed into category ( $Y 04=1, Y 05=2, Y 06=3, Y 07=4, Y 08=5, Y 09=6$,

$\mathrm{Y} 10=7, \mathrm{Y} 11=8, \mathrm{Y} 13=9$ )

Freehold is referring to building status either freehold or leasehold

$\mathrm{LA}$ is referring to land area

MFA is referring to main floor area

Position is referring to building position either end, middle or corner lot

Basic_building_component is referring to building structure include types of roof, floor and ceiling

Building is referring to building material either from wood_brick or brick

Maintenance is referring to maintenance status good or bad include inside and outside building

Composite_historical_charac is referring to historical variables include façade, architectural style, ensemble and authenticity

The log-log RTR model is given by:

MV $=1.037+$ Road $^{*}-149+$ Transaction length* ${ }^{*}-044+$ Freehold* $-.063+$ Position $^{*} .105+$ Basic building component*-

$.022+$ Building $^{*} .054+$ Maintenance ${ }^{*} .009+$ Composite_historical_charac* $-.075+\operatorname{lgR} \_L A^{*} .732+\operatorname{lgR} \_$MFA* ${ }^{*}-046$. 
Where;

$\mathrm{MV}$ is referring to market value

Road is referring to location of shophouse heritage property

Transaction_length is referring to year of transaction transformed into category (Y04 =1, Y05=2, Y06=3, Y07=4, Y08=5, Y09=6, $\mathrm{Y} 10=7, \mathrm{Y} 11=8, \mathrm{Y} 13=9$ )

Freehold is referring to building status either freehold or leasehold

$\lg R \_L A$ is referring to land area transformed into log and ranking form

IgR_MFA is referring to main floor area transformed into log and ranking form

Position is referring to building position either end, middle or corner lot

Basic_building_component is referring to building structure include types of roof, floor and ceiling

Building is referring to building material either from wood_brick or brick

Maintenance is referring to maintenance status good or bad include inside and outside building

Composite_historical_charac is referring to historical variables include façade, architectural style, ensemble and authenticity

In order to determine the better prediction model considering the aims of this study, the selected / best models were applied to the in-sample and out-sample observations. Table 7 and Table 8 show the results of the MAPE's linear MRA and MAPE's log-log of the RTR according to types of observation in-sample and out-sample observations.

As shown in Table 7, the average MAPE values of the linear MRA is $15.88 \%$, and for log-log RTR, $12.51 \%$ for in-sample observations. MAPE value is computed by

$$
\text { MAPE }=\left(\frac{\text { estimate price }- \text { actual price }}{\text { actual price }}\right) \times 100
$$

It measures the size of the error in percentage term. The lower the error, the better the predictive model. In property valuation, the parameters of a sale price (actual price) and within estimated value should not lease $\pm 5 \%$ to $\pm 10 \%$ (Baum 2006; Brown et al. 1998; Joslin 2005). However, we found that the average MAPE of in-sample both for linear MRA and log-log RTR are slightly higher than $10 \%$ which are $15.88 \%$ and $12.51 \%$. Table 8 demonstrates the results of MAPE values according to out-sample observation. The purpose of out-sample observation is to check the plausible of the model when applied to data that were not used in the model fitting exercise. The findings from out-sample observation show that the MAPE values for linear MRA are $51.96 \%$ and log-log RTR is $74.40 \%$. For out-sample observation, the MAPE values for linear MRA and log-log RTR exceed the acceptable parameters of $\pm 10 \%$. It is showing that, the models produce are not accurate because the differences were large.

Table 7. The results of MAPE's linear MRA and log-log RTR for in-sample observations

\begin{tabular}{|c|c|c|c|c|c|c|c|}
\hline Observation & Road's name & $\begin{array}{l}\text { Price } \\
\text { (Actual } \\
\text { value of } \\
\text { transaction } \\
\text { price) } \\
\text { (MYR) } \\
\end{array}$ & $\begin{array}{l}\text { Price } \\
\text { Linear MRA } \\
(\text { MYR) }\end{array}$ & $\begin{array}{l}\text { MAPE values } \\
\text { (Linear MRA) } \\
(\%)\end{array}$ & $\begin{array}{l}\text { IgRprice } \\
\text { (Actual value } \\
\text { of } \\
\text { transaction } \\
\text { price in } \\
\text { ranking form) }\end{array}$ & $\begin{array}{l}\text { IgRprice } \\
\text { estimated } \\
\text { (ranking) }\end{array}$ & $\begin{array}{l}\text { MAPE } \\
\text { values } \\
\text { (Log-log } \\
\text { RTR) } \\
(\%)\end{array}$ \\
\hline 1 & Temenggong & 850,000 & $752,864.21$ & (11.43) & 0.48 & 0.72 & 50.05 \\
\hline 2 & Ismail & 510,000 & $535,766.85$ & 5.05 & 1.15 & 1.14 & $(0.49)$ \\
\hline 3 & Tok Hakim & 550,000 & $653,891.50$ & 18.89 & 1.08 & 1.09 & 1.04 \\
\hline 4 & Hulu Pasar & 420,000 & $419,999.87$ & 0.00 & 1.26 & 1.26 & 0.33 \\
\hline 5 & Temenggong & 250,000 & $578,606.19$ & 131.44 & 1.28 & 0.98 & $(23.37)$ \\
\hline 6 & Ismail & 530,000 & $461,815.25$ & (12.87) & 1.11 & 1.13 & 1.48 \\
\hline 7 & Ismail & 600,000 & $567,031.90$ & $(5.49)$ & 1.02 & 1.12 & 9.64 \\
\hline 8 & Temenggong & 800,000 & $628,635.26$ & (21.42) & 0.81 & 0.98 & 21.08 \\
\hline 9 & Temenggong & 800,000 & $696,359.26$ & (12.96) & 0.81 & 0.90 & 10.97 \\
\hline 10 & Temenggong & 800,000 & $620,279.24$ & (22.47) & 0.81 & 1.01 & 23.66 \\
\hline 11 & Hulu pasar & 500,000 & $517,829.89$ & 3.57 & 1.20 & 1.16 & (3.93) \\
\hline 12 & Temenggong & 900,000 & $868,992.14$ & $(3.45)$ & 0.30 & 0.36 & 18.95 \\
\hline 13 & Tok hakim & 810,000 & $796,671.49$ & (1.65) & 0.60 & 0.53 & (11.91) \\
\hline 14 & Temenggong & 500,000 & $514,481.46$ & 2.90 & 1.20 & 1.17 & $(2.92)$ \\
\hline 15 & Temenggong & 600,000 & $765,494.26$ & 27.58 & 1.02 & 0.79 & $(23.10)$ \\
\hline 16 & Temenggong & 800,000 & $841,574.28$ & 5.20 & 0.81 & 0.68 & $(16.10)$ \\
\hline 17 & Ismail & 500,000 & $466,992.13$ & $(6.60)$ & 1.20 & 1.24 & 2.81 \\
\hline 18 & Temenggong & 640,000 & $687,194.15$ & 7.37 & 0.95 & 0.92 & (3.32) \\
\hline 19 & Temenggong & $1,050,000$ & $1035,518.20$ & $(1.38)$ & 0.00 & 0.05 & - \\
\hline \multicolumn{4}{|c|}{ Average of MAPE values for MRA } & $15.88 \%$ & \multicolumn{2}{|c|}{$\begin{array}{l}\text { Average of MAPE values for } \\
\text { RTR }\end{array}$} & $12.51 \%$ \\
\hline
\end{tabular}

Note: Negative figures are returned in bracket.

Table 8. The results of MAPE's linear MRA and log-log RTR for out-sample observations

\begin{tabular}{|c|c|c|c|c|c|c|}
\hline Observation & $\begin{array}{l}\text { Price } \\
\text { (Actual value of }\end{array}$ & $\begin{array}{l}\text { Rprice } \\
\text { Linear MRA }\end{array}$ & $\begin{array}{l}\text { MAPE values } \\
\text { (Linear MRA) }\end{array}$ & $\begin{array}{l}\text { IgRprice } \\
\text { (Actual }\end{array}$ & $\begin{array}{l}\text { IgRprice } \\
\text { estimated }\end{array}$ & $\begin{array}{l}\text { MAPE values } \\
\text { (Log-log RTR) }\end{array}$ \\
\hline
\end{tabular}




\begin{tabular}{lllllll}
\hline & $\begin{array}{l}\text { transaction price) } \\
\text { (MYR) }\end{array}$ & (MYR) & $(\%)$ & $\begin{array}{l}\text { value of } \\
\text { transaction } \\
\text { price in } \\
\text { ranking } \\
\text { form) }\end{array}$ & (ranking & (\%) \\
\hline 1 & 820,000 & 431787.69 & $(47.34)$ & 3.00 & 1.45 & 203.1 \\
2 & 450,000 & 1070067.47 & 137.79 & 17.00 & 0.13 & $(89.05)$ \\
3 & 650,000 & 318145.34 & $(51.05)$ & 9.00 & 1.52 & 58.87 \\
4 & 650,000 & 318145.34 & $(51.05)$ & 9.00 & 1.52 & 58.87 \\
5 & 618,100 & 526576.9 & $(14.81)$ & 9.50 & 1.16 & 18.35 \\
6 & 640,000 & 577854.66 & $(9.71)$ & 9.00 & 1.13 & 18.18 \\
\hline \multicolumn{7}{l}{} \\
\hline
\end{tabular}

Note: Negative figures are returned in bracket.

Table 9 summaries the applicability of MRA and RTR in valuing heritage property value. The MAPE is the one of the most widely used measures of forecast accuracy, due to its advantages of scale-independency and interpretability (Kim and Kim, 2016). The findings from in-sample shows that the MAPE values still in acceptable range. However, for out-sample the MAPE values has a large error and it is not good sign. It means that the model is not accurate to be used in estimating the value of heritage property values. What can be concluded here, the idea of comparing between MRA and RTR needs to be viewed more thoroughly. First, models have the different functional form (MRA-linear, RTR-log-log), second, they have different type of explanatory variables (the continuous variables of MRA were transformed into ranking form for RTR model), and lastly, the final value produce is different (MRAabsolute value, $R T R$ in ranking form).

Table 9. Summaries on applicability of MRA and RTR in valuing heritage property value

\begin{tabular}{llll}
\hline No & Criteria & MRA & RTR \\
\hline 1. & Adjusted R $\mathrm{R}^{2}$ of best model & $23.2 \%$ & $67.1 \%$ \\
2. & MSE & $4.661 \mathrm{E}+10$ & 0.187 \\
3. & The best functional form & Linear & Log-log \\
4. & MAPE value of in-sample & $15.8 \%$ & $12.51 \%$ \\
5. & MAPE value of out-sample & $51.96 \%$ & $74.40 \%$ \\
6. & Final / end value & Absolute value (MYR) & ranking \\
\hline
\end{tabular}

\subsection{Conclusion}

According to Mohamad et al. (2015), the sale comparison methods are the most preferable and accepted method by Malaysian valuers in valuing private heritage property even though there is a limitation in applying this method that associated with limited market evidence. Having regards to the weaknesses of the traditional method of sale comparison, this study test the applicability of the statistical method of analysis to conduct an assessment for heritage property valuation. The statistical methods are multiple regression analysis (MRA) and rank transformation regression (RTR). The use of MRA in estimating real estate values has been shown widely in the appraisal literature, however, this technique needs a large amount of data. While, the RTR has shown to be a successful technique for small samples (Mohamad, 2012). The results indicate that adopting statistical methods of valuation per se to overcome the issue of unavailability of market evidence still could not solve the consequences of the limited data problem. Therefore, from the presented case study, we can conclude that we couldn't simply make a direct comparison of MRA and RTR models because; 1) they have different functional form. However, we still can compare between these two models if we are only interested in value estimation. Even so, the predictive performance must be properly evaluated and 2) they have different number and types of explanatory variables. For example, for MRA model, land area (LA) is continuous variables while for RTR the LA (R_LA) were transformed into ranking form from highest to lowest. In practice, since the sale comparison method is the best method for valuing private heritage property, the future research will focus on improving the method for that specific application.

\section{Acknowledgements}

The authors express gratitude to the Valuation and Property Services Department of Kota Bharu and Kota Bharu Municipal Council for providing the data and the Malaysian Ministry of Education (MOE) for funding the research (FRGS: FRGS/1/2016/WAB03/UMK/02/1) and MyBrain15. Our gratitude also goes to the anonymous and suggestions on the early draft of this paper.

\section{References}

Baum, Christopher F. 2006. "An Introduction to Modern Econometrics Using Stata." : 341. http://www.stata-press.com/books/modern-econometrics-stata/

Brooks, Chris, and Sotiris Tsolacos. 2010. Real Estate Modelling and Forecasting. Cambridge University Press.

Boyce, B. N., Kinnard Jr, W. N., \& Kinnard, W. N. (1984). Appraising real property. Lexington Books.

218 
Brown, Gerald R, George A Matysiak, and Mark Shepherd. 1998. "Valuation Uncertainty and the Mallinson Report." Journal of Property Research 15(1): 1-13.

Cronan, Timothy, Donald Epley, and Larry Perry. 1986. "The Use of Rank Transformation and Multiple Regression Analysis in Estimating Residential Property Values with a Small Sample." Journal of Real Estate Research 1(1): 19-31.

Des Rosiers, François, Marius Thériault, and Paul-Y Villeneuve. 2000. "Sorting out Access and Neighbourhood Factors in Hedonic Price Modelling." Journal of Property Investment \& Finance 18(3): 291-315.

Deddis, W. (2002). Development of a geographic information system for mass appraisal of residential property. RICS Education Trust, 1(1), 4.

Iman, A. H. M., \& Chin, C. V. (2005). Modelling the Value of Location in the Prediction of Residential Property Value. Universiti Teknologi Malaysia.

Iman, Ronald L. 1974. "A Power Study of a Rank Transform for the Two-way Classification Model When Interaction May Be Present." Canadian Journal of Statistics 2(1-2): 227-39.

International Valuation Standards. 2011.

Joslin, Alexander. 2005. "An Investigation into the Expression of Uncertainty in Property Valuations." Journal of Property Investment \& Finance 23(3): 269-85.

Kim, J. (2005). The Performance Indicator of Industrial Property Market based on the Location Factors. Paper to be submitted to the 11th PRRES Annual Conference.

Kim, S. and Kim, H., 2016. A new metric of absolute percentage error for intermittent demand forecasts. International Journal of Forecasting, 32(3), pp.669-679.

Lazrak, Faroek, Peter Nijkamp, Piet Rietveld, and Jan Rouwendal. 2014. "The Market Value of Cultural Heritage in Urban Areas: An Application of Spatial Hedonic Pricing." Journal of Geographical Systems 16(1): 89-114. http://link.springer.com/10.1007/s10109-013-0188-1 (January 13, 2015).

McCluskey, W., Deddis, W. G., \& Lamont, I. (1998). The application of spatially derived location factors within a GIS environment. In PRESS Eighth Annual Conference (Vol. 11).

Mohamad, Junainah. 2012. "Assessment of Property Values in Thin Market Using Rank Transformation Regression and Multiple Regression Analysis." Universiti Teknologi Malaysia.

Mohamad, Junainah, Suriatini Ismail, Rosdi Ab Rahman, and Ahmad Rasdan Ismail. 2015. "Valuers' Perception on the Current Practice of Heritage Property Valuation in Malaysia." In 21st Annual Pacific-Rim Real Estate Society Conference, Kuala Lumpur, Malaysia.

Montgomery, Douglas C. 2008. Design and Analysis of Experiments. John Wiley \& Sons.

Moro, Mirko, Karen Mayor, Seán Lyons, and Richard S J Tol. 2013. "Does the Housing Market Reflect Cultural Heritage? A Case Study of Greater Dublin." Environment and Planning A 45(12): 2884-2903.

O'brien, Robert M. 2007. “A Caution Regarding Rules of Thumb for Variance Inflation Factors." Quality \& Quantity 41(5): 673-90.

Ruijgrok, E. C. M. (2006). The three economic values of cultural heritage: a case study in the Netherlands. Journal of Cultural Heritage, 7(3), $206-213$. http://doi.org/10.1016/j.culher.2006.07.002

Suriatini Ismail. 2005. "Hedonic Modelling of Housing Markets Using Geographical Information System (GIS) and Spatial Statistics: A Case Study of Glasgow, Scotland."

Thériault, Marius, François Des Rosiers, Paul Villeneuve, and Yan Kestens. 2003. "Modelling Interactions of Location with Specific Value of Housing Attributes." Property Management 21(1): 25-62.

VanVoorhis, Carmen R Wilson, and Betsy L Morgan. 2007. "Understanding Power and Rules of Thumb for Determining Sample Sizes." Tutorials in Quantitative Methods for Psychology 3(2): 43-50.

Wilson, Robert B. 1993. Nonlinear Pricing. Oxford University Press on Demand.

Yung, H. K., \& 容曉君. 2007. HKU Theses Online (HKUTO) "Architectural Heritage Conservation in Hong Kong: An Empirical Analysis." The University of Hong Kong (Pokfulam, Hong Kong). http://hub.hku.hk/bitstream/10722/52588/5/Abstract.pdf. 